$\sqrt{B}$

J. Bio-Sci. 26: 07-14, 2018

ISSN 1023-8654

http://www.banglajol.info/index.php/JBS/index

\title{
USE OF DEPROTEINISED LEAF JUICE OF MEDICAGO SATIVA L. FOR THE PRODUCTION OF $\alpha$-AMYLASE
}

\author{
S lliyas* \\ Department of Botany \\ Poona College of Arts, Science and Commerce, Camp. Pune- MS 41100, India
}

\begin{abstract}
Leaf protein concentration (LPC) is a good source of cyanocobalamine ( $\left.B_{12}\right)$, ascorbic acid (vitamin $\left.C\right)$ and folic acid (vitamin $\mathrm{B}_{9}$ ). After isolation of LPC from leaves the remaining by product is deproteinised leaf juice (DPJ) which is rich in water soluble carbohydrates, free amino acids, minerals, lipids and vitamins. The dry matter (DM) and nutrient composition of DPJ varies from species to species. The DM content in this fraction was found between 1.2 to $4.0 \%$. Six fungi were grown on the DPJ expressed from Medicago sativa, Anethum graveolens, Spinacia oleracea, Trigonella foenium-graecum, Coriandrum sativum and also on conventional GN medium to evaluate the suitability of DPJ as a medium for fungal growth and subsequent production of $\propto$-amylase. The efficiency of DPJ as a medium for fungal growth was evaluated and its value in microbial biotechnology for the production of $\propto$-amylase was tested. Increase in concentrate of flour in the DPJ there was simultaneous increase in the mycelial dry weight (MDW) production of the six fungi under investigation. On DPJ alone, the yield of MDW was between 76.0 and $89.5 \mathrm{mg}$ which increased to $164.5,131.0$ and $117.0 \mathrm{mg}$ respectively under the influence of the flours of wheat, sorghum and maize respectively. Maximum response to the enrichment of DPJ by flour was noticed with $A$. niger. As with the increase in growth of fungi with increasing concentration of flour, the activity of amylase also increased. On an average it was $34-96 \mathrm{U} / \mathrm{ml}$ when the fungi were grown on DPJ alone, which increased to 301, 265 and $276 \mathrm{U} / \mathrm{ml}$ under the influence of flours.
\end{abstract}

Key words: Amylase, DPJ, LPC, Lucerne, Aspergillus

\section{Introduction}

The deproteinised leaf juice is rich in water soluble nutrients present in the leaves. It contributes to more than $50 \%$ of the fresh weight from green foliage which is fractionated for the production of pressed crop residue (PCR) and leaf protein concentration (lliyas 2011). It is rich in water soluble carbohydrates, free amino acids, minerals, lipids and vitamins (lliyas and Badar 2010a). It also contains small fraction of protein (lliyas and Badar 2010). The effect of additives on chlorophyll content in wet LPC prepared from juice of Medicago sativa L. is more effective (lliyas 2010, lliyas and Mungikar 2003). Some bioinformatical aspects protein isolated from Medicago sativa L. viz. A comparative study of protein structure visualization tools for various display capabilities were studied (Ansari and lliyas 2011). A comparative study of different properties provided by protein structure visualization tools (lliyas and Ansari 2013). Implementation of image processing in agriculture sector. Production of amylase of DPJ of four different plants (lliyas 2013).

This product, with 4 to $5 \%$ solids, contains large proportion of nitrogen and phosphorus. The dry matter and nutrient composition of DPJ varies from species to species. At Rothemsted Experimental Station in UK the DM content in this fraction was found to be between 1.2 to $4.0 \%$. On an average, the $\mathrm{N}$ and carbohydrate content in DM of DPJ are 3\% and 40\% respectively. The dominant monosaccharides in DPJ are glucose and

*Author for correspondence: sayyed_iliyas@yahoo.com 
fructose. However, the contents of these reducing sugars in DPJ are subject to a great change, depending upon the species used for Green Crop Fractionation (GCF) and maturity of the plants used. This by-product should be disposed properly in order to avoid local environmental bio-pollution (lliyas and Mungikar 2005). Proper exploit of the DPJ is also useful in making DPJ as a commercial by product (Josephin and lliyas 2005, lliyas 2014a, lliyas 2014b). During present investigation the efficiency of DPJ as a medium for fungal growth was evaluated and its value in microbial biotechnology for the production of enzyme $\propto$-amylase was tested.

\section{Materials and Methods}

\section{Preparation of DPJ}

The green foliages from Medicago sativa, Anethum graveolens, Trigonella foenium-graecum, Coriandrom sativum and Spinacia oleracea were used for fractionation. The juice released during fractionation was employed for the preparation of LPC by heat coagulation and the DPJ released after precipitation and isolation of proteins in juice was collected. The samples of DPJ were dried in hot air oven at $65^{\circ} \mathrm{C}$. The dry DPJ was stored in sealed glass jar until used. Sufficient care was taken to minimise absorption of moisture by the DPJ samples.

\section{Preparation of culture media}

The conventional gram negative (GN) medium was prepared by dissolving glucose $10 \mathrm{~g}, \mathrm{KNO}_{3} 2.5 \mathrm{~g}$, $\mathrm{KH}_{2} \mathrm{PO}_{4} 1 \mathrm{~g}$ and $\mathrm{MgSO}_{4} 0.5 \mathrm{~g}$ in one litre of distilled water. Simultaneously, the dry DPJ was dissolved in distilled water at various concentrations and used as a medium for growing fungi.

\section{Sterilization}

Twenty five $\mathrm{ml}$ of either GN medium or the aqueous solution of DPJ was poured into $250 \mathrm{ml}$ conical flask. The flasks were then plugged with non absorbent cotton and autoclaved at $15 \mathrm{lbs}$ for 30 minutes.

\section{Inoculation}

The autoclaved flasks were transferred to the inoculation room for inoculation with fungi. The stock cultures of the fungi were collected from the laboratory of department. It was maintained on potato dextrose agar (PDA) medium. The inoculation was always done in UV chamber under aseptic condition. The inoculum in the form of spore suspension was prepared by adding $10 \mathrm{ml}$ sterile distilled water to six day old slope culture of the fungi. The medium, either GN or DPJ, was inoculated with 5 drops of the spore suspension which contained $5 \times 10^{2}$ spores per microscopic field. The inoculated flasks were incubated at room temperature.

\section{Collection of microbial biomass}

The flasks were inoculated for 8 to 12 days after inoculation. The fungal biomass was harvested by filtration through Whatman 1 filter paper. The mycelial biomass was dried along with the filter paper in an oven at 65 $\pm 5^{\circ} \mathrm{C}$ till constant weight. The yield of mycelial dry weight (MDW) was then recorded by substracting the weight of filter paper from the weight recorded for dry mycelium.

A blank or control flask was also processed simultaneously, during all experiments wherein flasks containing either GN or DPJ medium remained uninoculated. The MDW was corrected each time by substracting the dry weight obtained from uninoculated flasks.

During all experiments, the culture filtrate was collected after harvesting the microbial biomass, centrifuged at $10,000 \mathrm{rpm}$ for 15 minutes at $0^{\circ} \mathrm{C}$ and supernatant was used as the crude enzyme extract as source of $\propto$ amylase. 


\section{Assay of $\propto$-amylase}

Amylase activity was determined using modified method described by Bern (1955). The starch solution (1\%) for which was prepared by adding a paste of soluble starch to boiling phosphate buffer $(20 \mathrm{mM})$ and stirring constantly with glass rod. This solution was filtered with Whatman paper No.1 before use.

Starch solution $(1 \mathrm{ml})$ was taken in a glass tube and placed in water bath at $40^{\circ} \mathrm{C}$ for temperature equilibration. $1 \mathrm{ml}$ properly diluted crude enzyme extract (either from GN media or DPJ) was added to preincubated starch. The reaction mixture was incubated at $40^{\circ} \mathrm{C}$ for 20 minutes and the reaction was terminated by adding $0.4 \mathrm{ml}$ DNS reagent prepared by adding $1 \mathrm{~g}$ of 3,5 dinitrosalysilic acid (DNS) to $20 \mathrm{ml}$ of $2 \mathrm{~N} \mathrm{NaOH}$ and $30 \mathrm{~g}$ sodium potassium tartarate. The blank was prepared similarly but without substrate i.e. starch. The tubes were kept in boiling water bath after addition of DNS reagent for 5 minutes, cooled immediately under tap water and reaction mixture was diluted by adding $3 \mathrm{ml}$ distilled water and the amylase activity was determined by measuring the optical density at $460 \mathrm{~nm}$ and comparing it with the calibration curve. The calibration curve was established with maltose $(0.2$ to $2 \mathrm{mg} / 2 \mathrm{ml}$ water) and was used to convert the optical density into the amount of maltose released. Amylae activity was expressed in terms of $\mathrm{mg}$ of maltose liberated within one minute when the reaction mixture was incubated for 20 minutes at $40^{\circ} \mathrm{C}$ with 1 $\mathrm{ml}$ of the crude enzyme extract.

The unit of enzyme activity $(U)$ was defined as the number of micromoles of $\propto-1-4$ glycosidic bonds hydrolyzed per minute and was calculated as described by using following equation:

$$
\text { Unit }(U)=\frac{\mu g \text { of maltose equivalents produced } / \mathrm{min} / \mathrm{ml} \text { of digest }}{342}
$$

Where, 342 is the molecular weight of maltose.

\section{Production of $\propto$-amylase}

During the first experiment, A. niger, A. flavus, Helminthosporium oryzae, Fusarium oxysporum, Phytophthora infestans and Curvularia lunata were grown on the DPJ expressed from Medicago sativa, Anethum graveolens, Spinacia oleracea, Trigonella foenium-graecum, Coriandrum sativum and also on conventional GN medium to evaluate the suitability of DPJ as a medium for fungal growth and subsequent production of enzyme $\propto$-amylase. The culture filtrates left after isolating the mycelium after 7 days of growth of these fungi were employed to assay $\propto$-amylase production as described above.

\section{Effect of different flours on production of $\propto$-amylase}

During present experiment, wheat, Sorghum and maize flours were added at different concentrations (5 to 50 $\mathrm{mg} / \mathrm{ml}$ ) to DPJ prepared from lucerne to enhance the production of $\propto$-amylase. Six fungi were inoculated to the DPJ enriched with flour and the yield of microbial biomass was recorded along with the measurement of $\propto$-amylase activity.

\section{Results and Discussion}

Deproteinised leaf juice, left behind isolating leaf protein concentrate from the heated juice is considered as a by-product of 'Green Crop Fractionation' system. As this product is rich in soluble nutrients from the plant its random disposal will not only cause environmental bio-pollution but also make the process of GCF inefficient or less economic. In view of its high cost stressed its proper use to make this process more valuable. 
Earlier investigations from this laboratory indicated suitability of DPJ as a medium for growing useful fungi (lliyas and Mungikar 2005) indicated suitability of lucerne DPJ for cultivating A. niger and production of $\propto$ amylase.

During present study, the efficiency of DPJ as a medium for fungal growth was evaluated and its value in microbial biotechnology for the production of $\propto$-amylase was tested.

\section{Effect of different flours on $\propto$-amylase production}

In microbial biotechnology, employed for the production of enzymes from fungi or other microbes, the composition growth medium is modified as per the requirement. It was observed that the DPJ from lucerne at a concentration of $2 \%$ is suitable for growing fungi. Though it is a rich source of nitrogen $(\mathrm{N})$ for fungal growth the low level of carbohydrates limit further growth. Iliyas (2014) found increased growth of fungi when the DPJ was supplemented with either glucose or lactose (a source of carbohydrate). However, on large scale cultivation of fungi on DPJ the use of glucose may be expensive. In view of these attempts were made during present experiment to study the effect of wheat, sorghum and maize flours as a source of carbohydrate on the growth of various fungi and $\propto$-amylase production by them.

The results presented in Table 1-3 indicate that with the increase in concentrate of flour in the DPJ there was simultaneous increase in the mycelial dry weight (MDW) production of the six fungi under investigation. On DPJ alone, on an average, the yield of MDW was between 76.0 and $89.5 \mathrm{mg}$ which increased to 164.5 , 131.0 and $117.0 \mathrm{mg}$, respectively under the influence of the flours of wheat, sorghum and maize, respectively. Maximum response to the enrichment of DPJ by flour was noticed with $A$. niger.

Table 1. Effect of different concentrations of wheat flour on growth of fungi on DPJ of Medicago sativa L.

\begin{tabular}{|c|c|c|c|c|c|c|c|c|c|c|c|}
\hline \multirow{3}{*}{ Fungi } & \multicolumn{11}{|c|}{ Mycelial dry weight (mg) } \\
\hline & \multicolumn{11}{|c|}{$\mathrm{mg} / \mathrm{ml} \mathrm{DPJ}$} \\
\hline & 0 & 5 & 10 & 15 & 20 & 25 & 30 & 35 & 40 & 45 & 50 \\
\hline Aspergillus niger & 105 & 107 & 121 & 137 & 151 & 175 & 189 & 210 & 230 & 244 & 268 \\
\hline $\begin{array}{l}\text { Aspergillus } \\
\text { flavus }\end{array}$ & 95 & 097 & 099 & 103 & 109 & 113 & 119 & 125 & 131 & 137 & 144 \\
\hline H. oryzae & 98 & 105 & 109 & 111 & 120 & 125 & 131 & 137 & 145 & 155 & 169 \\
\hline F. oxysporum & 91 & 097 & 101 & 110 & 117 & 121 & 126 & 132 & 135 & 140 & 143 \\
\hline $\begin{array}{l}\text { Cunvularia } \\
\text { lunata }\end{array}$ & 61 & 065 & 070 & 079 & 082 & 086 & 093 & 096 & 101 & 107 & 112 \\
\hline P. notatum & 87 & 097 & 101 & 111 & 117 & 121 & 127 & 133 & 139 & 143 & 151 \\
\hline Mean & 89.5 & 94.6 & 100.0 & 108.5 & 116.0 & 123.5 & 130.8 & 138.8 & 148.8 & 154.3 & 164.5 \\
\hline SD & 13.9 & 13.8 & 14.2 & 16.9 & 20.1 & 26.4 & 28.8 & 34.5 & 39.7 & 42.6 & 49.2 \\
\hline CV & 15.5 & 14.5 & 14.2 & 15.6 & 17.4 & 21.3 & 22.0 & 24.9 & 26.7 & 27.6 & 29.9 \\
\hline
\end{tabular}


Table 2. Effect of different concentrations of Sorghum flour on growth of fungi on DPJ of Medicago sativa L.

\begin{tabular}{|c|c|c|c|c|c|c|c|c|c|c|c|}
\hline \multirow{3}{*}{ Fungi } & \multicolumn{11}{|c|}{ Mycelial dry weight (mg) } \\
\hline & \multicolumn{11}{|c|}{$\mathrm{mg} / \mathrm{ml} \mathrm{DPJ}$} \\
\hline & 0 & 5 & 10 & 15 & 20 & 25 & 30 & 35 & 40 & 45 & 50 \\
\hline Aspergillus niger & 90 & 093 & 099 & 101 & 117 & 121 & 129 & 134 & 144 & 150 & 161 \\
\hline Aspergillus flavus & 98 & 101 & 117 & 121 & 125 & 130 & 135 & 140 & 143 & 145 & 149 \\
\hline H. oryzae & 83 & 085 & 088 & 089 & 093 & 097 & 101 & 111 & 117 & 120 & 127 \\
\hline F. oxysporum & 61 & 069 & 075 & 077 & 082 & 086 & 093 & 097 & 101 & 103 & 106 \\
\hline Curvularia lunata & 68 & 073 & 077 & 081 & 085 & 087 & 089 & 093 & 094 & 099 & 101 \\
\hline P. notatum & 99 & 101 & 102 & 107 & 109 & 113 & 117 & 121 & 125 & 129 & 137 \\
\hline Mean & 83.1 & 86.7 & 93.0 & 96.0 & 101.8 & 105.6 & 110.6 & 116 & 120.6 & 124.3 & 13.1 \\
\hline SD & 14.3 & 11.6 & 14.7 & 15.3 & 16.1 & 16.7 & 17.5 & 17.5 & 190.3 & 19.2 & 21.5 \\
\hline CV & 17.2 & 13.4 & 15.8 & 15.9 & 15.1 & 15.8 & 15.8 & 15.0 & 15.7 & 15.2 & 16.5 \\
\hline
\end{tabular}

Table 3. Effect of different concentrations of maize flour on growth of fungi on DPJ of Medicago sativa L.

\begin{tabular}{|c|c|c|c|c|c|c|c|c|c|c|c|}
\hline \multirow{3}{*}{ Fungi } & \multicolumn{11}{|c|}{ Mycelial dry weight (mg) } \\
\hline & \multicolumn{11}{|c|}{$\mathrm{mg} / \mathrm{ml} \mathrm{DPJ}$} \\
\hline & 0 & 5 & 10 & 15 & 20 & 25 & 30 & 35 & 40 & 45 & 50 \\
\hline Aspergillus niger & 87 & 090 & 103 & 107 & 113 & 117 & 123 & 129 & 131 & 134 & 141 \\
\hline Aspergillus flavus & 93 & 095 & 097 & 101 & 105 & 107 & 111 & 113 & 117 & 121 & 125 \\
\hline H. oryzae & 76 & 076 & 079 & 083 & 085 & 089 & 093 & 099 & 101 & 103 & 107 \\
\hline F. oxysporum & 62 & 063 & 069 & 073 & 077 & 081 & 085 & 091 & 093 & 095 & 099 \\
\hline Curvularia lunata & 78 & 085 & 089 & 095 & 101 & 111 & 117 & 121 & 125 & 129 & 121 \\
\hline P. notatum & 60 & 063 & 069 & 071 & 076 & 081 & 086 & 091 & 095 & 097 & 099 \\
\hline Mean & 76.0 & 78.6 & 84.3 & 88.3 & 92.8 & 97.6 & 102.5 & 107.3 & 108.1 & 113.1 & 117 \\
\hline SD & 12.0 & 12.4 & 13.0 & 13.6 & 14.2 & 14.5 & 15.1 & 14.6 & 14.6 & 15.4 & 16.2 \\
\hline CV & 15.8 & 15.8 & 15.5 & 15.4 & 15.3 & 14.9 & 14.7 & 13.6 & 13.5 & 13.7 & 13.8 \\
\hline
\end{tabular}

Tables 4 to 6 give an account on $\propto$-amylase production under the influence of the flours of these three grains. As with the increase in growth of fungi with increasing concentration of flour, the activity of enzyme amylase also increased. On an average it was 34 to $96 \mathrm{U} / \mathrm{ml}$ when the fungi were grown on DPJ alone, which increased to 301,265 and $276 \mathrm{U} / \mathrm{ml}$ under the influence of flours. 
Table 4. Effect of different concentrations of wheat flour on production of amylase by fungi grown on DPJ of Medicago sativa L.

\begin{tabular}{|c|c|c|c|c|c|c|c|c|c|c|c|}
\hline \multirow{3}{*}{ Fungi } & \multicolumn{11}{|c|}{ Amylase activity (U/ml) } \\
\hline & \multicolumn{11}{|c|}{ Conc. of flour (mg/ml DPJ) } \\
\hline & 0 & 5 & 10 & 15 & 20 & 25 & 30 & 35 & 40 & 45 & 50 \\
\hline Aspergillus niger & 86 & 89 & 162 & 266 & 291 & 850 & 919 & 940 & 977 & 974 & 951 \\
\hline Aspergillus flavus & 135 & 139 & 176 & 217 & 245 & 261 & 291 & 305 & 323 & 231 & 171 \\
\hline H. oryzae & 57 & 61 & 89 & 135 & 160 & 167 & 167 & 208 & 220 & 236 & 229 \\
\hline F. oxysporum & 20 & 22 & 34 & 36 & 116 & 174 & 199 & 185 & 181 & 144 & 144 \\
\hline Curvularia lunata & 21 & 22 & 34 & 34 & 77 & 100 & 135 & 167 & 171 & 158 & 153 \\
\hline Penicillium notatum & 66 & 68 & 80 & 139 & 144 & 153 & 162 & 229 & 275 & 283 & 158 \\
\hline Mean & 64.1 & 66.8 & 95.8 & 137.0 & 172 & 284 & 312 & 339 & 357 & 337 & 301 \\
\hline SD & 39.5 & 40.3 & 55.8 & 85.4 & 73.6 & 257 & 275 & 272 & 281 & 288 & 292 \\
\hline CV & 61.6 & 60.3 & 58.3 & 62.0 & 42.8 & 90.6 & 88.3 & 80.3 & 78.9 & 85.6 & 97 \\
\hline
\end{tabular}

Table 5. Effect of different concentrations of sorghum flour on production of amylase by fungi grown on DPJ of Medcago sativa L.

\begin{tabular}{l|lll|l|l|l|l|l|l|l|l}
\hline \multirow{2}{*}{ Fungi } & \multicolumn{10}{c}{ Amylase activity (U/ml) } \\
\cline { 2 - 13 } & \multicolumn{10}{c}{ Conc. of flour (mg/ml DPJ) } \\
\cline { 2 - 13 } & 0 & 5 & 10 & 15 & 20 & 25 & 30 & 35 & 40 & 45 & 50 \\
\hline \multirow{2}{*}{ A. niger } & 187 & 190 & 208 & 369 & 457 & 470 & 527 & 527 & 520 & 470 & 458 \\
A. flavus & 47 & 48 & 57 & 66 & 89 & 164 & 272 & 291 & 293 & 256 & 275 \\
H. oryzae & 160 & 185 & 190 & 229 & 270 & 323 & 360 & 366 & 382 & 366 & 380 \\
F. oxysporum & 77 & 89 & 121 & 137 & 171 & 178 & 194 & 213 & 227 & 203 & 181 \\
C. lunata & 89 & 94 & 130 & 139 & 213 & 227 & 236 & 254 & 231 & 185 & 185 \\
P. notatum & 21 & 23 & 38 & 89 & 91 & 135 & 139 & 178 & 190 & 182 & 116 \\
\hline Mean & 96.8 & 104 & 124 & 171 & 215 & 249 & 288 & 304 & 307 & 276 & 265 \\
SD & 58.8 & 63.2 & 62.3 & 102 & 125 & 115 & 126 & 115 & 113 & 106 & 119 \\
CV & 60.8 & 60.3 & 50.2 & 59.4 & 58.3 & 46.2 & 43.9 & 37.9 & 36.8 & 38.7 & 45.0 \\
\hline
\end{tabular}


Table 6. Effect of different concentrations of maize flour on production of amylase by fungi grown on DPJ of Medcago sativa L.

\begin{tabular}{|c|c|c|c|c|c|c|c|c|c|c|c|}
\hline \multirow{3}{*}{ Fungi } & \multicolumn{11}{|c|}{ Amylase activity (U/ml) } \\
\hline & \multicolumn{11}{|c|}{ Conc. of flour (mg/ml DPJ) } \\
\hline & 0 & 5 & 10 & 15 & 20 & 25 & 30 & 35 & 40 & 45 & 50 \\
\hline Aspergillus niger & 79 & 80 & 103 & 139 & 155 & 169 & 190 & 213 & 231 & - & - \\
\hline Aspergillus flavus & 23 & 25 & 41 & 68 & 80 & 103 & 184 & 254 & 300 & 300 & 275 \\
\hline H. oryzae & 17 & 34 & 43 & 139 & 167 & 190 & 227 & 233 & 282 & 587 & 300 \\
\hline F. oxysporum & 48 & 59 & 75 & 89 & 121 & 167 & 245 & 254 & 222 & 158 & 135 \\
\hline Curvularia lunata & 28 & 34 & 61 & 70 & 75 & 94 & 139 & 162 & 190 & 167 & 144 \\
\hline P. notatum & 14 & 27 & 36 & 61 & 70 & 91 & 116 & 139 & 171 & 171 & 160 \\
\hline Mean & 34.8 & 43.1 & 59 & 94.3 & 111 & 135 & 173 & 209 & 232 & 276 & 202 \\
\hline SD & 22.5 & 19.8 & 23.4 & 32.6 & 38.9 & 40.5 & 48 & 44.2 & 46.0 & 163 & 70.0 \\
\hline CV & 64.9 & 45.9 & 39.6 & 34.5 & 34.9 & 29.8 & 27.6 & 21.1 & 19.7 & 59 & 34.5 \\
\hline
\end{tabular}

It was thus concluded that enrichment of DPJ with flours as a source of carbohydrate was useful in increasing the production of $\propto$-amylase. These flours might have contributed to the medium other nutrients apart from carbohydrates, like minerals, amino acids, vitamins etc. resulting in increased growth and enzyme production.

\section{Conclusion}

During the present course of investigation it is observed that suitability of DPJ as a medium for growing useful fungi. The results obtained during the experiments undertaken by author on DPJ for its potential as microbial growth medium indicated suitability of lucerne DPJ for cultivating A. niger. It was thus concluded from the experiments undertaken during present investigation that for maximum production of $\propto$-amylase take place by $A$. niger. The $\propto$-amylase production increased with the addition of wheat flour.

\section{Acknowledgement}

Author is thankful to Prof. Anil M. Mungikar, former Head, Department of Botany, Dr. Babasaheb Ambedkar Marathwada University, Aurangabad for kind help, valuable guidance and encouragement during the course of investigation. 


\section{References}

Ansari SN and lliyas S (2011). A comparative study of protein structure visualization tools for various display capabilities. Bioscience Discovery: An International Journal of Life Sciences, 2(2): 222-226.

Field BP (1955). Methods in Enzymology. (Colowick SP and Kaplan NO Eds.). Academic Press, New York Vol.1, 149 pp.

lliyas S (2010). Effect of additives on chlorophyll content in wet Ipc prepared from juice of Medicago sativa Linn. Bioinfolet-A Quarterly Journal of Life Sciences, 7(3): 251-259.

lliyas S (2011). Study of LPC and PCR prepared from Radish (Raphanus Sativus Linn.) Plant Sciences Feed, 1(6): 8892.

lliyas S (2013). Production of amylase of DPJ of four different plants, International Journal of Basic and Applied Chemical Sciences, 3(4): 48-61.

lliyas S (2014a). Effect of different flours on $\propto$-amylase production. American Journal of Scientific and Industrial Research, 5(3): 104-109.

lliyas S (2014b). Production of a-amylase on deproteinised leaf juice prepared from different plants. Plant Sciences Feed, 4(4): 31-35.

lliyas S and Ansari SN (2013). A comparative study of different properties provided by protein structure visualization tools. International Journal of Basic and Applied Chemical Sciences, 3(1): 1-6.

lliyas S and Badar KV (2010). LPC: A good source of cyanocobalamine (B12), ascorbic acid (Vitamin C) and folic acid (Vitamin B9). Journal of Experimental Sciences, 1(2): 12-14.

lliyas S and Badar KV (2010). Estimation of thiamine, riboflavin and pyridoxine from LPC of some plants. Journal of Experimental Sciences, 1(2): 15-17.

lliyas S and Mungikar AM (2003). Changes in chlorophyll content of lucerne leaf juice during storage. Geobios, 30(4): 299-300.

lliyas S and Mungikar AM (2005). Use of deproteinised leaf juice (DPJ) in microbial biotechnology. Pollution Research, 24(2): 459.

Josephin EDB and lliyas S (2005). Deproteinised leaf juice as a medium for fungal growth and for production of protease. Geobios, 32(4): 282.

Sami $P$ and lliyas S (2014). A review on implementation of image processing in agriculture sector. Science Research Reporter, 4(1): 71-78. 